\title{
EFECTUL ŞOCULUI TERMIC A TEMPERATURILOR SUBOPTIMALE POZITIVE ŞI A PREPARATULUI REGLALG ASUPRA INDICILOR GERMINATIVI AI SEMINT,ELOR DE CASTRAVETE CUCUMIS SATIVUS L
}

\author{
Cauș $M$. \\ Institutul de Genetică, Fiziologie şi Protecţie a Plantelor, Chișinău, Republica Moldova, \\ e-mail: mcausmcv@yahoo.com.
}

\begin{abstract}
Cucumber (Cucumis sativus L.), cv Concurent and forms as Plai, $\mathrm{F}_{1}$, ELITA, $\mathrm{F}_{1}$; ASSIA, $\mathrm{F}_{1}$; Viorel, $\mathrm{F}_{1 \text { și }}$ Cernomor, $\mathrm{F}_{1}$ seeds treated with distillate water (control) or water solutions of Reglalg preparation $\left(1 / 100\right.$ and $1 / 1000$ dilutions) were germinated at $27^{\circ} \mathrm{C}$ (control) or at different sub optimal positive low temperature $\left(15^{\circ} \mathrm{C}, 13^{\circ} \mathrm{C}, 10^{\circ} \mathrm{C}, 8^{\circ} \mathrm{C}, 6^{\circ} \mathrm{C}\right.$ and $\left.4^{\circ} \mathrm{C}\right)$ to study germination characteristics. Final germination percent of $\mathrm{cv}$ Concurent seeds and germination energy decreased, while the conditional number of days, required for germination of one seed, increased with the decrease of temperature. The temperature of $13^{\circ} \mathrm{C}$ is the minimum below which all cucumber seeds do not germinate. Application of Reglalg preparation (dilution 1/1000) had a beneficial effect on the germination parameters under suboptimal temperature of $15^{\circ} \mathrm{C}$.
\end{abstract}

Key words: Cucumis sativus L., Reglalg, positive low temperatures stress, seed germination

\section{Introducere}

Germinarea semințelor reprezintă un proces foarte complex, fiind reglat de un șir de factori ai mediului ambiant (5). Plante originare din zonele tropicale și subtropicale fiind expuse acțiunii temperaturilor suboptimale, mai mici de $12^{\circ} \mathrm{C}$, suferă diverse deteriorări, care se reflectă asupra desfășurării ulterioare a proceselor fiziologice, ce determină creșterea și productivitatea plantelor $(1,7)$.

Castravetele (Cucumis sativus L.), specie, ce se cultivă în regiunile tropicale şi temperate, este pretenţios faţă de căldură, iar seminţele germinează bine la un optim de 24$28^{\circ} \mathrm{C}$ (3). Temperatura optimă de germinare a semințelor de castravete este în funcție de specie, soi, linii, forme și factorii de mediu $(3,8,9,5,10)$.

Germinarea slabă la temperaturile suboptimale este un simptom comun pentru speciile sensibile expunerii acțiunii temperaturilor joase pozitive. Cultivarele și liniile de castravete diferă semnificativ în ceea ce privește cerințele lor pentru temperatura optimă și minimă pentru germinare $(4,8,9)$.

Se cunoaște că condițiile climaterice de primăvară se caracterizează prin schimbări fluctuase ale temperaturii mediului ambiant care pot avea un efect nefavorabil pentru germinarea și creșterea timpurie a multor culturi horticole, inclusiv pentru castravete, cu impunerea limitări semnificative privind formarea ulterioară a productivității $(1,5,7)$. Din acest motiv, numeroase programe de cercetare sunt iniţiate cu scopul de a dezvolta cultivare cu adaptabilitate sporită a germinației, creșterii și dezvoltării ulterioare a plantelor în condiții 
adverse ale temperaturilor scăzute ale mediului \% (5). De asemenea, s-a dovedit că pentru îmbunătăţirea proprietăților germinative şi de creştere a plantelor în condiţii nefavorabile se aplică diferite procedee, inclusiv utilizarea compuşilor biostimulatori $(2,6)$.

În lucrarea de față se aduc date despre efectele tratamentelor semințelor de castravete (Cucumis sativus L.), cv Concurent cu diferite doze suboptimale ale temperaturilor scăzute pozitive şi a preparatului Reglalg asupra indicilor germinativi.

\section{Materiale şi metode}

Ca obiect de studiu au servit seminţele de castravete Cucumis sativus L. soiul Concurent. Pentru comparație au fost luate în studiu și formele de Cucumis sativus L. ca Plai, $\mathrm{F}_{1}$ : ELITA, $\mathrm{F}_{1}$; ASSIA, $\mathrm{F}_{1}$; Viorel, $\mathrm{F}_{1}$; Cernomor, $\mathrm{F}_{1}$ de castravete Cucumis sativus L., oferite de către Institutul de Cercetări Ştiinţifice pentru Agricultură din Tiraspol. Înainte de germinare seminţele au fost bine spălate, dezinfectate, apoi îmbibate în apă distilată (martor) sau soluţie a preparatului Reglalg (diluția 1/100) pe parcursul a 24 ore, şi plasarea ulterioară pentru germinare în incubatorul de germinare cu umiditatea aerului de $70-80 \%$, la întuneric, la temperatura de $27^{\circ} \mathrm{C}$ (martorul) sau la diferite doze a temperaturilor scăzute pozitive. Pe parcursul procesului de germinare a fost efectuată evaluarea indicilor germinativi. Proprietăţile germinative au fost evaluate conform metodelor expuse în lucrarea (3).

\section{Rezultate şi discuţii}

Influenţa diferitor doze a temperaturilor scăzute pozitive asupra indicilor germinativi ai semințelor de castravete Cucumis sativus L.

În tabelul 1 sunt prezentate datele despre influenţa diferitor doze a temperaturilor scăzute pozitive $\left(15^{\circ} \mathrm{C}, 13^{\circ} \mathrm{C}, 10^{\circ} \mathrm{C}, 8^{\circ} \mathrm{C}, 6^{\circ} \mathrm{C}\right.$ şi $\left.4^{\circ} \mathrm{C}\right)$ asupra indicilor germinativi ai seminţelor de castravete Cucumis sativus L. , soiul Concurent. Procentul germinației facultative (GF) a scăzut odată cu scăderea temperaturii. La temperatura suboptimală de $15^{\circ} \mathrm{C}$, semințele de castravete soiul Concurent au demonstrat o germinare facultativă de $100 \%$, analogic variantei martor (100\%), dar energia de germinare (EG) a fost cu aproximativ $24 \%$ mai mică, față de varianta martor. Totodată, numărul de zile necesar pentru germinarea unei semințe la temperatura de $15^{\circ} \mathrm{C}$ a fost mai mare, constituind 4,66 zile, față de 1,15 în varianta martor (tabelul 1).

Tabelul 1. Influenţa diferitor doze a temperaturilor scăzute pozitive asupra indicilor germinativi ai seminţelor de castravete Cucumis sativus L., soiul Concurent.

\begin{tabular}{|l|c|c|c|}
\hline $\begin{array}{l}\text { Temperatura de } \\
\text { germinare a seminţelor }\end{array}$ & $\begin{array}{l}\text { Germinarea } \\
\text { facultativă (GF), } \\
\%\end{array}$ & $\begin{array}{l}\text { Energia de } \\
\text { germinare (EG), } \\
\%\end{array}$ & $\begin{array}{l}\text { Numărul condiţional de zile } \\
\text { necesar pentru germinarea 1 } \\
\text { (unei) seminţe }\end{array}$ \\
\hline$+27^{\circ} \mathrm{C}$ (martor) & 100 & 84,62 & 1,15 \\
\hline$+15^{\circ} \mathrm{C}$ & 100 & 64.29 & 4,66 \\
\hline$+13^{\circ} \mathrm{C}$ & 50 & 10 & 9,2 \\
\hline$+10^{\circ} \mathrm{C}$ & 0 & 0 & 0 \\
\hline$+8^{\circ} \mathrm{C}$ & 0 & 0 & 0 \\
\hline$+6^{\circ} \mathrm{C}$ & 0 & 0 & 0 \\
\hline$+4^{\circ} \mathrm{C}$ & 0 & 0 & 0 \\
\hline
\end{tabular}

Din datele tabelului 1 se vede, că din temperaturile suboptimale testate, temperatură de

$13^{\circ} \mathrm{C}$ este cea mai joasă temperatura la care germinează semințele de castravete soiul 
Concurent. La această temperatură $\left(13^{\circ} \mathrm{C}\right)$ semințele de castravete au prezentat diferențe semnificative, privind indicii germinativi ai seminţelor. La temperatura de $13^{\circ} \mathrm{C} \mathrm{s}-\mathrm{a}$ înregistrat cea mai mică germinare facultativă $(50 \%)$, manifestând o energie de germinare de $\approx 4,3$ și $\approx 8,5$ ori mai mică comparativ cu temperatura de $13^{\circ} \mathrm{C}$ și respectiv varianta martor. Iar numărul condițional de zile necesar pentru germinarea unei semințe la temperatura suboptimală de $13^{\circ} \mathrm{C}$ a fost de 9,2 zile, față de 4,66 zile și 1,15 zile în variantele cu aplicarea temperaturii de $15^{\circ} \mathrm{C}$ și respectiv varianta martor.

Deoarece s-au constatat diferențe semnificative, în ceia ce privește influența temperaturilor suboptimale asupra procesului de germinare a semințelor de castravete, care este în funcție de doză, soi, forme sau linii de Cucumis sativus L.(4,5,8) noi am testat indicii germinativi ai seminţelor diferitor forme de castravete Cucumis sativus L., comparativ cu Cucumis sativus L., soiului Concurent la temperatura suboptimală minimă de germinare de $13^{\circ} \mathrm{C}$ (tabelul 2). .

Tabelul 2. Indicii germinativi a seminţelor diferitor forme de castravete Cucumis sativus L. de la Institutul din Tiraspol, comparativ seminţele Cucumis sativus L., soiului Concurent la temperatura suboptimală minimă de germinare de $13^{\circ} \mathrm{C}$.

\begin{tabular}{|l|c|c|c|}
\hline $\begin{array}{l}\text { Soiul şi formele de } \\
\text { castravete } \text { Cucumis } \\
\text { sativus } \mathrm{L} .\end{array}$ & $\begin{array}{l}\text { Germinarea } \\
\text { facultativă } \\
(\mathrm{GF}) \mathrm{la} 13^{\circ} \mathrm{C}, \\
\%\end{array}$ & $\begin{array}{l}\text { Energia de } \\
\text { germinare la } \\
13^{\circ} \mathrm{C}, \%\end{array}$ & $\begin{array}{l}\text { Numărul condiţional de } \\
\text { zile necesar pentru } \\
\text { germinarea 1 (unei) } \\
\text { seminţe la 13 }{ }^{\circ} \mathrm{C}\end{array}$ \\
\hline Soiul Concurent & $\mathbf{5 0}$ & $\mathbf{1 0}$ & $\mathbf{9 , 2}$ \\
\hline Plai, $\mathrm{F}_{1}$ & $\mathbf{7 5}$ & $\mathbf{5 0}$ & $\mathbf{7 , 6}$ \\
\hline ELITA, $\mathrm{F}_{1}$ & 0 & 0 & 0 \\
\hline ASSIA, $\mathrm{F}_{1}$ & 0 & 0 & 0 \\
\hline Viorel, $\mathrm{F}_{1}$ & 0 & 0 & 0 \\
\hline Cernomor, $\mathrm{F}_{1}$ & 0 & 0 & 0 \\
\hline
\end{tabular}

Evaluarea comparativă a indicilor germinativi ai seminţelor diferitor forme de castravete Cucumis sativus L. (Plai, $\mathrm{F}_{1}$ : ELITA, $\mathrm{F}_{1}$; ASSIA, $\mathrm{F}_{1 ;}$ Viorel, $\mathrm{F}_{1 \text { și }}$ Cernomor, $\mathrm{F}_{1}$ ) cu soiul Concurent la temperatura suboptimală minimă de germinare de $13^{\circ} \mathrm{C}$ relevă diferențe semnificative (tabelul 2). Din datele acestei tabele se poate observa, că din formele de castravete Cucumis sativus L. testate la temperatura suboptimală minimă $\left(13^{\circ} \mathrm{C}\right)$ de germinare, stabilită pentru soiul Concurent, numai forma Plai, F1 a germinat. Semințele acesteia au demonstrat o germinare facultativă și o energie de germinare de 1,5 și respectiv 5 ori mai mare comparativ cu soiul Concurent. Numărul condițional de zile necesar pentru germinarea unei semințe a formei Plai F1, a fost mai mic - 7,6 zile, față de 9,2 zile pentru soiul Concurent (tabelul 2).

Aşa dar, valorile indicilor germinativi ai seminţelor de Cucumis sativus L. sunt determinate de forma şi soiul de castravete. Temperatură minimă de germinare pentru seminţele de Cucumis sativus L. soiul Concurent este de $13^{\circ} \mathrm{C}$.

Evaluarea influenței utilizării preparatului Reglalg asupra schimbărilor caracteristicilor germinative ale seminţelor de castravete la temperatura suboptimală pozitivă de $15^{\circ} \mathrm{C}$. 
Studierea utilizării preparatului Reglalg la tratarea seminţelor de castravete şi consecinţele acestor tratamente asupra parametrilor germinativi ai semințelor de castravete, soiul Concurent la temperatura suboptimală de $15^{\circ} \mathrm{C}$ sunt prezentate în tabelul 3

Tabelul 3. Influenţa diferitor doze a preparatului Reglalg asupra indicilor germinativi ai seminţelor de castravete Cucumis sativus L., soiul Concurent la temperatura suboptimală de $15^{\circ} \mathrm{C}$.

\begin{tabular}{|l|c|c|c|}
\hline $\begin{array}{l}\text { Modul de tratare a } \\
\text { seminţelor }\end{array}$ & $\begin{array}{l}\text { Germinarea } \\
\text { facultativă (GF) } \\
\text { la } 15^{\circ} \mathrm{C}, \%\end{array}$ & $\begin{array}{l}\text { Energia de } \\
\text { germinare la } \\
15^{\circ} \mathrm{C} \text { în ziua a } \\
4, \%\end{array}$ & $\begin{array}{l}\text { Numărul condiţional de } \\
\text { zile necesar pentru } \\
\text { germinarea 1 (unei) } \\
\text { seminţe la 15 }\end{array}$ \\
\hline Martor, H2O & 100 & 64.29 & 4.66 \\
\hline Reglalg, 1/100 & 90.63 & $59.38^{*}$ & $5.84^{*}$ \\
\hline Reglalg, 1/1000 & 100 & 71.88 & 4.635 \\
\hline
\end{tabular}

Se poate observa, că seminţele, ce au germinat la temperatura de $15^{\circ} \mathrm{C}$ manifestă o energie de germinare mai scăzută, 59,38\%, comparativ cu martorul (64.29\%) și varianta cu diluția $1 / 1000$ a preparatului Reglalg $(71.88 \%)$. Germinarea unei seminţe la temperatura de $15^{\circ} \mathrm{C}$ necesită mai mult timp, 5,84 zile, față de $\approx 4,6$ zile în varianta martor și varianta utilizării soluției cu diluția 1/1000 a preparatului Reglalg (tabelul 3).

În varianta cu aplicarea semințelor de castravete soluția de Reglalg, diluția 1/1000 numărul condiţional de zile necesar pentru germinarea unei seminţe la temperatura de $15^{\circ} \mathrm{C}$ este nesemnificativ mai mic (4.63 zile) decât în varianta martor (4.66 zile), şi semnificativ mai mic decât în varianta cu aplicarea preparatului Reglalg, diluția 1/100 (5.84 zile), ceea ce demonstrează o energie de germinare mai sporită $(71,88 \%)$ în varianta cu aplicarea Reglalgului, 1/1000, comparativ cu varianta martor (64.29\%) şi aplicarea diluţiei 1/100 a soluției de Reglalg (71.88\%). Prin urmare, tratarea seminţelor cu Reglalg, diluţia 1/1000, poate fi utilizată pentru a obține o germinare mai sporită în condiții de temperatură suboptimală.

\section{Concluzii}

1. Rezultatele cercetărilor demonstrează, că indicii germinativi ai seminţelor de Cucumis sativus L. sunt determinate de forma şi soiul de castravete.

2. Temperatură minimă de germinare pentru seminţele de Cucumis sativus L. soiul Concurent este de $13^{\circ} \mathrm{C}$.

3. Tratarea seminţelor de castravete înainte de germinare cu soluţie apoasă a preparatului Reglalg diluția $1 / 1000$ și germinarea ulterioară la temperatură suboptimală de $15^{\circ} \mathrm{C}$ a avut efecte benefice asupra parametrilor de germinare.

\section{Bibliografie}

1. Allen D.J., Ort D.R. Impact of chilling temperatures on photosynthesis in warmclimate plants. // Trends Plant Sci., 2001, vol. 6, p. 36-42. 
2. Cauș M., Dascaliuc A. Influenţa biostimulatorului Reglalg asupra reacţiei plantulelor de castravete (Cucumis sativus L.) la şocul termic.// Buletinul Academiei de Ştiinţe a Moldovei, Ştiinţele vieţii, 2019, nr. 2 (338), p. 85-95.

3. Kłosińska U., Kozik E.U., Nowicki M., Wehner T.C. Low temperature seed germination of cucumber: genetic basis of the tolerance trait .// Journal Hort. Research, 2013, vol. 21(2), p.125-130.

4. Li J., Cui H., Zhang M. The relationship between low-temperature germination and chilling tolerance in cucumber. // Cucurbit Genet. Coop. Rpt., 1998, vol.21, p.11-13.

5. Markovskaya E.F., Sherudilo E.G.,Sysoeva M.I. Cucumber seed germination: Effect and after-effect of temperature treatments. // Global Science and Biotechnology, 2007, vol. 1 (2), p. 25-31.

6. Ramin A. A. Improving Germination Performance and chilling tolerance in cucumber seedlings with Paclobutrazol. // Intern. .J. Vegetable Sci., 2009, vol.15, p.173-184

7. Saltveit M.E., Morris L.L. Overview on chilling injury of horticultural crops. // In: Wang CY (ed) Chilling Injury of Horticultural Crops. CRC Press Inc., Boca Raton, FL, 1990, p. 3-15. ISBN 0-8493-5736-5.

8. Wehner T.C. Screening for low-temperature germination ability in cucumber.// Hort. Science, 1981, vol.16, p.399.

9. Wehner T.C. Genetic variation for low-temperature germination ability in cucumber.// Cucurbit Genet. Coop. Rpt., 1982, vol. 5, p.16-17.

10. Yu J.Q., Zhou Y.H., Huang L.F., Allen D.J. Chill-induced inhibition of photosynthesis: genotypic variation within Cucumis sativus. // Plant Cell Physiol., 2002, vol. 43(10), p.1182-1188. 